\title{
Jätekompostilannoitusten vaikutus maahan ja kasveihin monivuotisessa peltokokeessa
}

\author{
Tiina Tontti ${ }^{1)}$, Ansa Palojärvi ${ }^{2)}$, Helvi Heinonen-Tanski ${ }^{3)}$, Arja Halinen ${ }^{4)}$ ja Päivi Karinen ${ }^{3)}$ \\ ${ }^{1)}$ MTT Kasvintuotannon tutkimus, Lönnrotinkatu 3,50100 Mikkeli, tiina.tontti@mtt.fi \\ ${ }^{2)}$ MTT Kasvintuotannon tutkimus, 31600 Jokioinen, ansa.palojarvi@mtt.fi \\ ${ }^{3)}$ Kuopion yliopisto, Ympäristötieteen laitos, $P L 1627,70211$ Kuopio, heinotan@uku.fi. \\ paivi.karinen@uku.fi \\ ${ }^{4)}$ Metsähallitus, Kalevankatu 8, 40100 Jyväskylä, arja.halinen@metsa.fi (nykyinen osoite)
}

\section{Tiivistelmä}

Yhdyskuntien orgaanista jätettä kompostoimalla syntyy stabiloitua lannoitus- ja maanparannusainetta. Ne voisivat olla käyttökelpoisia peltoviljelyssä, mutta niiden käyttöön on arveltu liittyvän raskasmetalli- ja hygieniariskejä. Luonnonmukaisesti hoidetussa peltokokeessa käytettiin teollisesti kompostoituja hyvälaatuisia jätekomposteja kolmesti kuuden vuoden viljelykierrossa. Kompostityyppien raaka-aineet olivat 1) synty-pistelajiteltu yhdyskuntien biojäte, 2) syntypistelajitellun yhdyskuntabiojätteen ja mädätetyn puhdistamolietteen seos, ja 3) naudanlannan ja oljen seos. Koeasetelma oli osaruutukoe 4 toistolla, jossa pääruudussa oli levitystaso ja osaruudussa kompostityyppi. Vuonna 2000 perustetun kokeen viljelykierto oli suojavilja / apila-heinä / apila-heinä / ohra / peruna / suojavilja. Keväisin ja ennen kompostilevityksiä (vuosina 2000, 2004 ja 2005) otettiin näytteet maasta ja käytettävistä komposteista. Kasvinäytteet otettiin kunkin sadonkorjuun yhteydessä ja maanäytteet joka syksynä. Komposti- ja maanäytteistä analysoitiin ravinteiden ja raskasmetallien kokonais- sekä liukoiset pitoisuudet. Komposteista ja maasta määritettiin hygieniaindikaattoreita ja maan mikrobiston kokonaismäärää ja aktiivisuutta kuvaavia muuttujia. Kompostilannoitus annettiin peltoviljelykasvien ravinnerajoitusten mukaisesti, jolloin ravinnepitoisuuksiltaan vaihtelevien kompostien levitysmäärät olivat eri vuosina 3$50 \mathrm{t} / \mathrm{ha}$.

Vaikka kompostien kypsyys vaihteli paljon, niiden laatu oli verraten hyvä. Kompostien kokonaistypestä alle $13 \%$ oli keväällä levityksen aikana liukoisessa muodossa. Biojätekompostissa tuli kasvien käyttöön enemmän typpeä, kun taas biojätepuhdistamolietekompostissa oli paljon kokonaisfosforia mutta hyvin vähän liukoista fosforia. Jätekompostien raskasmetallipitoisuudet ja peltoon levitetyt määrät olivat suuremmat kuin lantakompostilla, mutta EU:n luomutuotantoon kelpaavan talousjätekompostin raskasmetallipitoisuudet ylittyivät vain biojätepuhdistamolietekompostin kuparin ja sinkin pitoisuudessa. Hygieniaindikaattorien pitoisuudet komposteissa olivat alhaisia ja ne ilmensivät kompostointiprosessin tehon vaihtelua eri vuosina. Maan ravinnepitoisuudet muuttuivat vähän kompostilannoitusten seurauksena, ainoastaan lantakomposti nosti liukoisen kaliumin pitoisuutta. Hygieniaindikaattorien ja maan mikrobiologisten ominaisuuksien perusteella maan laadun heikentymistä ei havaittu. Maan mikrobiologinen toiminta jopa hieman tehostui. Jätekompostien käytöllä ei kuitenkaan havaittu olevan voimakkaita maanparannusvaikutuksia, osittain alhaisten kompostimäärien ja osittain maan hyvän luontaisen viljavuuden vuoksi. Lähes kaikki kompostikäsittelyt lisäsivät levitysvuosien kasvisatoa lannoittamattomaan kontrolliin verrattuna. Tulosten perusteella ainakin valikoituja yhdyskuntajäteperäisiä komposteja voitaisiin hyödyntää lannoitteina ja maanparannusaineina ilman merkittäviä haittavaikutuksia.

\section{Asiasanat:}

komposti, yhdyskuntajäte, puhdistamoliete, ravinteet, raskasmetallit, fekaaliset koliformit, typen mineralisaatio 


\section{Johdanto}

Suomen jätelainsäädännön keskeiset periaatteet ovat jätteiden synnyn ehkäiseminen, hyötykäytön lisääminen ja jätehuollon aiheuttamien haittojen vähentäminen. EU:n kaatopaikkadirektiivi (1999/31/EY) rajoittaa biohajoavien jätteiden läjittämistä kaatopaikoille ja ohjaa jäsenvaltioita lisäämään biohajoavien jätteiden kierrätystä ja hyötykäyttöä, esimerkiksi kompostoimalla tai mädättämällä. Prosessien lopputuotteet sisältävät eriasteisesti hajonnutta orgaanista ainesta ja kasvinravinteita, jotka voidaan hyödyntää lannoitteina ja maanparannusaineina. Luonnonmukaisen tuotannon tavoitteena on luonnontalouden toimintoihin sopeutettu viljelmä, jonka tuotantotekniikassa korostetaan maan luontaisen viljavuuden hoitoa ja mahdollisimman suljettua ravinnekiertoa (Rajala 2004). Luomutuotannon merkittävä haaste on kasvien ravinnetarpeen tyydyttäminen ilman helppoliukoisten mineraalilannoitteiden käyttöä niin, että satotaso pysyy viljelyn taloudellisen kestävyyden kannalta riittävänä. Yhdyskuntien lajitellusta biojätteestä tuotetun kompostin käyttöä ei sallita suomalaisessa luomutuotannossa keräysjärjestelmien epäluotettavuuden vuoksi.

Biohajoavan jäteperäisen materiaalin hyödyntäminen kompostoituna kasvintuotannossa voisi edesauttaa biohajoavan jätteen hyötykäyttöä koskevien tavoitteiden saavuttamista, ravinteiden ja eloperäisen aineksen määrien sekä kasvukunnon ylläpitämistä viljelymaassa. Kompostien käyttö lannoitteena edellyttää kuitenkin yleensä täydennyslannoitusta, sillä kompostien ravinnesuhteet vastaavat harvoin suoraan kasvien ravinnetarpeita. Tavanomaisessa viljelyssä kompostien lannoitusvaikutusta voidaan täydentää mineraalityppilannoitteella ja luomuviljelyssä esimerkiksi liha- ja luujauhoilla. Kompostien käytön riskitekijöinä pidetään etenkin raskasmetallien kertymistä peltomaahan sekä kompostin patogeenisten mikrobien aiheuttamia hygieenisiä riskejä. Mikäli eloperäisen aineksen hajoaminen kompostissa on vielä suurimmaksi osaksi kesken, eli komposti on ns. raakaa, voi riskinä olla myös ravinteiden sitoutuminen eloperäisen aineksen hajoamiseen liittyviin mikrobiprosesseihin ja kompostin sisältämät, kasveille haitalliset eli fytotoksiset aineet. Tutkimuksen tavoitteena oli selvittää, onko yhdyskuntajätteestä tuotettujen hyvälaatuisten kompostien käyttö kasvintuotannossa hyödyllistä ja millaisia haittavaikutuksia ilmenee yhdyskuntajäteperäisten kompostien toistuvassa lannoituskäytössä.

\section{Aineisto ja menetelmät}

Luonnonmukaisesti hoidetussa peltokokeessa käytettiin yhdyskuntajätekomposteja kolmesti kuuden vuoden viljelykierrossa. Kompostityyppien raaka-aineet olivat 1) syntypistelajiteltu yhdyskuntien biojäte, 2) syntypistelajitellun yhdyskuntabiojätteen ja mädätetyn puhdistamolietteen seos, ja 3) naudanlannan ja oljen seos. Yhdyskuntajätettä sisältävät kompostit saatiin yhteistyökumppaneiden kompostointilaitoksilta, joissa oli valittu taustatietojen mukaan prosessin laadukkaasti läpäisseet, vähintään kolme kuukautta kypsytetyt hyvälaatuiset kompostierät tutkimuksen käyttöön. Aumakompostoitu naudanlantakomposti saatiin viljelijältä.

Koeasetelma oli osaruutukoe (4 kerrannetta), jossa pääruudussa oli levitystaso ("pieni"/"suuri”) ja osaruudussa kompostityyppi (Biojäte, BioLiete, Lanta). Koe perustettiin vuonna 2000 Juvalle EteläSavoon (HtMr) ja kokeen viljelykierto oli suojavilja / apila-heinä / apila-heinä / ohra / peruna / suojavilja. Kompostilannoitus annettiin peltoviljelykasvien ravinnerajoitusten ja lannoitussuositusten mukaisesti, joko typen tai fosforin määrän perusteella, jolloin kompostien levitysmäärät vaihtelivat suuresti. Keväisin ja ennen kompostilevityksiä (vuosina 2000, 2004 ja 2005) otettiin kokoomanäytteet maasta ja käytettävistä komposteista. Kasvinäytteet otettiin kunkin sadonkorjuun yhteydessä ja maanäytteet joka syksynä. Näytteenotto- ja analyysimenetelmät on esitetty yksityiskohtaisesti loppuraporteissa (Lehtonen et al. 2003, Halinen et al. 2007).

Komposti- ja maanäytteistä analysoitiin ravinteiden ja raskasmetallien kokonais- sekä liukoiset pitoisuudet; viljavuusfosfori ja -kalium (HAAc -uutto 1:10, Agricultural Research Centre 1986), kokonaisfosfori $\left(\mathrm{H}_{2} \mathrm{SO}_{4}-\mathrm{H}_{2} \mathrm{O}_{2}\right.$-HF-uutto, Bowman 1988), raskasmetallien kokonaispitoisuudet (ARuutto, ISO 11466), raskasmetallien liukoiset pitoisuudet (HAAc-EDTA-uutto, Lakanen \& Erviö 1971). Typen kokonaispitoisuus määritettiin sekä maa- että kasvinäytteistä Leco CN-2000-laitteella (Leco Corporation 1998). Komposteista ja suuremmalla kompostimäärällä lannoitetusta maasta määritettiin hygieniaindikaattoreina mm. fekaaliset koliformit SFS-EN ISO 9308-1 standardissa esitetyillä varmistuskokeilla pintaviljelynä (mFC, SFS 4088). Hygienia määritettiin ennen kasvukautta otetuista kontrollimaan näytteistä sekä suuremmalta kompostilannoituksen tasolta 2 viikkoa kompostilevityksen jälkeen ja samana syksynä otetuista maanäytteistä. Maan mikrobiston kokonaismäärää ja aktiivisuutta tutkittiin useilla menetelmillä, $\mathrm{mm}$. typen kierron potentiaalista aktiivisuutta kuvaava 
typen nettomineralisaatio mitattiin anaerobisen inkubaation avulla kompostilannoitetusta maasta syksyisin (Canali \& Benedetti 2006).

\section{Tulokset ja tulosten tarkastelu}

Vaikka kompostien kypsyys vaihteli paljon, niiden laatu oli verraten hyvä. Kaikissa käytetyissä kompostierissä kompostien kokonaistypestä alle $13 \%$ oli liukoista keväällä levityksen aikaan ja kompostityyppien keskiarvoina sitäkin alempi (Taulukko 1). Kokeessa käytetyt kompostimäärät vaihtelivat suuresti, sillä viljelykierrossa eri vuosina käytettyjen kasvilajien ravinnetarpeet olivat erilaiset ja myös ravinnesisällöissä eri kompostityyppien välillä oli eroja. Kokeen alkaessa vuonna 2000 apilanurmen suojaviljalle annettiin 9-45 t/ha komposteja. Vuoden 2005 suojaviljan lannoitus oli hieman suurempi, mutta perunan kompostilannoitus vuonna 2004 selvästi edellisiä pienempi (Taulukko 2). Biojätekompostissa tuli kasvien käyttöön hieman enemmän typpeä kuin muissa kompostityypeissä, kun taas BioLiete-kompostissa oli paljon kokonaisfosforia mutta hyvin vähän liukoista fosforia. Jätekompostien raskasmetallipitoisuudet ja peltoon levitetyt määrät olivat suuremmat kuin Lanta-kompostilla, mutta vain kupari ja sinkki ylittivät EU:n luomutuotantoon kelpaavan talousjätekompostin raskasmetallipitoisuudet.

Taulukko 1. Peltokokeessa käytettyjen kompostityyppien keskimääräiset ravinne- ja raskasmetallipitoisuudet kolmen käytetyn kompostierän keskiarvona. Vertailuarvoina taulukossa esitetään kansallisten lannoitevalmistesäädösten sekä EU:n luonnonmukaisen tuotannon säädösten mukaiset suurimmat sallitut raskasmetallipitoisuudet sekä aiempia suomalaisia biojätekompostien tuloksia.

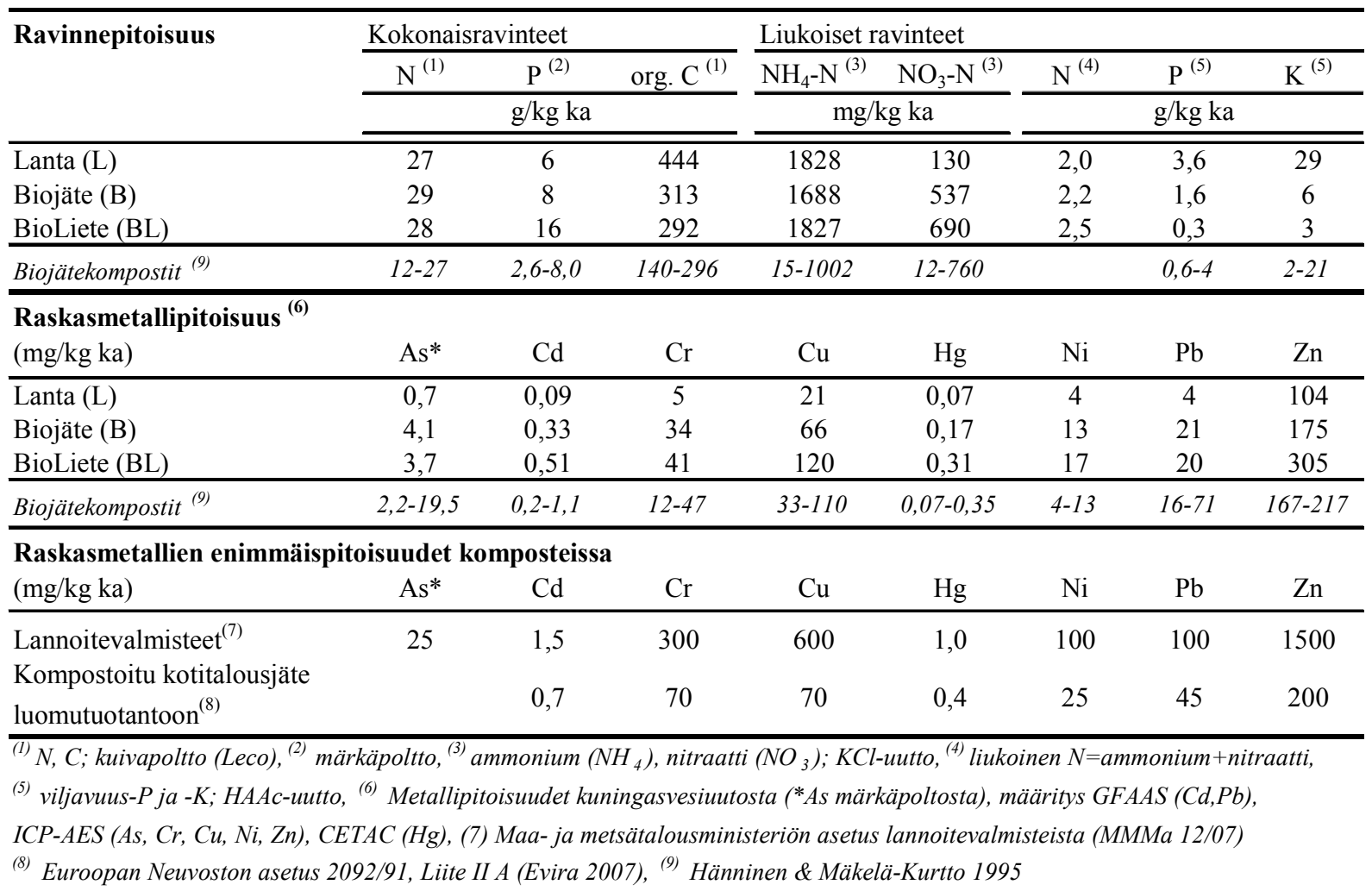


Taulukko 2. Peltokokeessa levitetyt kompostimäärät ja komposteissa annettu kokonaistyppi sekä liukoisen typen määrä keväällä kompostilannoituksen aikaan. (kompostityypit L=Lanta, B=Biojäte, BL=BioLiete)

\begin{tabular}{|c|c|c|c|c|c|c|c|c|c|c|c|c|c|c|c|c|c|c|}
\hline & \multicolumn{6}{|l|}{2000} & \multicolumn{6}{|l|}{2004} & \multicolumn{6}{|l|}{2005} \\
\hline & \multicolumn{3}{|c|}{ Pieni lannoitus } & \multicolumn{3}{|c|}{ Suuri lannoitus } & \multicolumn{3}{|c|}{ Pieni lannoitus } & \multicolumn{3}{|c|}{ Suuri lannoitus } & \multicolumn{3}{|c|}{ Pieni lannoitus } & \multicolumn{3}{|c|}{ Suuri lannoitus } \\
\hline & $\mathrm{L}$ & $\mathrm{B}$ & $\mathrm{BL}$ & $\mathrm{L}$ & $\mathrm{B}$ & BL & $\mathrm{L}$ & $\mathrm{B}$ & $\mathrm{BL}$ & $\mathrm{L}$ & $\mathrm{B}$ & $\mathrm{BL}$ & $\mathrm{L}$ & $\mathrm{B}$ & $\mathrm{BL}$ & $\mathrm{L}$ & $\mathrm{B}$ & $\mathrm{BL}$ \\
\hline Kompostimäärä (t/ha) & 17 & 23 & 9 & 33 & 45 & 18 & 5 & 3 & 3 & 9 & 6 & 5 & 25 & 26 & 23 & 50 & 52 & 46 \\
\hline Kokonais-N (kg/ha) & 367 & 257 & 127 & 712 & 503 & 253 & 45 & 63 & 37 & 90 & 119 & 74 & 194 & 298 & 347 & 389 & 596 & 693 \\
\hline Liukoinen N (kg/ha) & 10 & 23 & 9 & 20 & 44 & 18 & 3 & 5 & 2 & 6 & 10 & 4 & 25 & 18 & 44 & 49 & 36 & 89 \\
\hline
\end{tabular}

Maan ravinnepitoisuudet muuttuivat varsin vähän erityyppisten kompostien käytön seurauksena, ainoastaan Lanta-kompostin suuri liukoisen kaliumin pitoisuus nosti maan liukoisen kaliumin pitoisuutta (Taulukko 3). Maan liukoisen fosforin ja kaliumin pitoisuus näytti kokeen lopussa hieman nousseen suuremmalla lannoitustasolla. Syynä oli todennäköisesti saman vuoden keväällä annettu suurehko kompostilannoitus. Haitallisten metallien osalta kompostikäsitellyt ruudut eivät poikenneet nollaruuduista. Koeruutujen raskasmetallipitoisuudet alittivat selvästi raja-arvot, jotka valtioneuvoston puhdistamolietteiden käyttöä koskevassa päätöksessä (Vnp 282/1994) asetetaan peltomaalle, jolle puhdistamolietteitä voidaan käyttää. Kadmiumin kokonaispitoisuudet (kuningasvesiuutto) kokeen alussa vaihtelivat välillä 0,17 ja $0,24 \mathrm{mg} / \mathrm{kg} \mathrm{ka}$ ja loppupitoisuudet välillä 0,20 ja $0,25 \mathrm{mg} / \mathrm{kg} \mathrm{ka}$ eri maaruuduista. Kokonaislyijylle vastaavat arvot olivat alussa 7,9 - 10,6 mg/kg ka ja lopussa 5,7 - 9,1 mg/kg ka. Tässä tutkimuksessa kuparin ja sinkin pitoisuudet maassa pääsääntöisesti laskivat alkutilanteesta kokeen loppuun mentäessä kaikilla kompostilannoituskäsittelyillä sekä kokonais- että liukoisten pitoisuuksien osalta (Taulukko 3). Sinkin pitoisuudessa löytyi lannoitustasojen välillä oleva ero jo ennen ensimmäistä kompostilannoitusta, eivätkä kompostilannoitukset muuttaneet tilannetta. Etenkin pienemmällä lannoitustasolla kompostilannoitettujen ruutujen pintamaan kuparin ja sinkin pitoisuus oli hyvin lähellä lannoittamattoman 0-kontrollin pitoisuuksia.

Mäntylahti \& Laakso (2002) selvittivät Etelä-Savon alueella vuonna 2000 otetuista pintamaanäytteistä raskasmetallien pitoisuuksia kuningasvesiuutolla (ISO 11466). Heidän tutkimuksessaan mineraalimaalajeilla havaittujen kadmiumpitoisuuksien keskiarvo oli $0,103 \mathrm{mg} / \mathrm{kg}$ (vaihteluväli 0,045 0,426 ) ja lyijypitoisuuden keskiarvo $8,7 \mathrm{mg} / \mathrm{kg}$ (vaihteluväli 3,1-18,4), kun taas kuparipitoisuuden keskiarvo oli 14,7 mg/kg (vaihteluväli 4,9-33,0) ja sinkkipitoisuuden keskiarvo 40,4 mg/kg (vaihteluväli 9,9-95,0).

Taulukko 3. Kompostilannoituskokeen pintamaan ravinne- ja raskasmetallipitoisuuksia alkutilanteessa keväällä 2000 (alku) ja lopussa syksyllä 2005 (loppu), sekä kuuden vuoden koejakson aikana kolmessa kompostilannoituksessa koekäsittelyille yhteensä lisätyt määrät (lisätty).

\begin{tabular}{|c|c|c|c|c|c|c|c|c|c|c|c|c|}
\hline & \multicolumn{3}{|c|}{ Kokonaistyppi } & \multicolumn{3}{|c|}{ Kokonaisfosfori } & \multicolumn{3}{|c|}{ Liukoinen fosfori } & \multicolumn{3}{|c|}{ Liukoinen kalium } \\
\hline & $\begin{array}{l}\text { alku } \\
\mathrm{g} / \mathrm{kg} \mathrm{ka}\end{array}$ & $\begin{array}{l}\mathrm{kg} / \mathrm{ha} \\
\text { lisätty }\end{array}$ & $\begin{array}{l}\text { loppu } \\
\mathrm{g} / \mathrm{kg} \mathrm{ka}\end{array}$ & $\begin{array}{l}\text { alku } \\
\mathrm{g} / \mathrm{kg} \mathrm{ka}\end{array}$ & $\begin{array}{l}\mathrm{kg} / \mathrm{ha} \\
\text { lisätty }\end{array}$ & $\begin{array}{l}\text { loppu } \\
\mathrm{g} / \mathrm{kg} \mathrm{ka}\end{array}$ & $\begin{array}{l}\text { alku } \\
\mathrm{mg} / \mathrm{kg} \mathrm{ka}\end{array}$ & $\begin{array}{l}\mathrm{kg} / \mathrm{ha} \\
\text { lisätty }\end{array}$ & $\begin{array}{l}\text { loppu } \\
\mathrm{mg} / \mathrm{kg} \mathrm{ka}\end{array}$ & $\begin{array}{l}\text { alku } \\
\mathrm{mg} / \mathrm{kg} \mathrm{ka}\end{array}$ & $\begin{array}{l}\mathrm{kg} / \mathrm{ha} \\
\text { lisätty }\end{array}$ & $\begin{array}{l}\text { loppu } \\
\mathrm{mg} / \mathrm{kg} \mathrm{ka}\end{array}$ \\
\hline 0-kontrolli & 2,0 & 0 & 1,6 & 1,7 & 0 & 1,7 & 20 & 0 & 16 & 102 & 0 & 52 \\
\hline Lanta $_{\text {pieni }}$ & 2,0 & 606 & 1,8 & 1,7 & 138 & 1,7 & 18 & 92 & 16 & 104 & 713 & 104 \\
\hline Biojäte $_{\text {pieni }}$ & 2,0 & 618 & 1,7 & 1,8 & 196 & 1,7 & 19 & 39 & 16 & 100 & 157 & 64 \\
\hline BioLiete $_{\text {pieni }}$ & 2,0 & 510 & 1,7 & 1,7 & 292 & 1,7 & 23 & 4 & 18 & 108 & 61 & 65 \\
\hline Lanta $_{\text {suuri }}$ & 2,0 & 1191 & 1,9 & 1,8 & 270 & 1,6 & 28 & 181 & 25 & 117 & 1399 & 196 \\
\hline Biojäte $_{\text {suuri }}$ & 1,9 & 1218 & 1,8 & 1,8 & 388 & 1,7 & 26 & 76 & 23 & 114 & 308 & 90 \\
\hline \multirow[t]{3}{*}{ BioLiete $_{\text {suuri }}$} & 1,9 & 1020 & 1,9 & 1,7 & 584 & 1,7 & 27 & 9 & 22 & 115 & 121 & 84 \\
\hline & \multicolumn{3}{|c|}{ Kupari (kokonaispitoisuus) } & \multicolumn{3}{|c|}{ Liukoinen kupari } & \multicolumn{3}{|c|}{ Sinkki (kokonaispitoisuus) } & \multicolumn{3}{|c|}{ Liukoinen sinkki } \\
\hline & $\begin{array}{l}\text { alku } \\
\mathrm{mg} / \mathrm{kg} \mathrm{ka}\end{array}$ & $\begin{array}{l}\text { g/ha } \\
\text { lisätty }\end{array}$ & $\begin{array}{l}\text { loppu } \\
\mathrm{mg} / \mathrm{kg} \mathrm{ka}\end{array}$ & $\begin{array}{l}\text { alku } \\
\mathrm{mg} / \mathrm{kg} \mathrm{ka}\end{array}$ & $\begin{array}{l}\mathrm{g} / \mathrm{ha} \\
\text { lisätty }\end{array}$ & $\begin{array}{l}\text { loppu } \\
\mathrm{mg} / \mathrm{kg} \mathrm{ka}\end{array}$ & $\begin{array}{l}\text { alku } \\
\mathrm{mg} / \mathrm{kg} \mathrm{ka}\end{array}$ & $\begin{array}{l}\mathrm{kg} / \mathrm{ha} \\
\text { lisätty }\end{array}$ & $\begin{array}{l}\text { loppu } \\
\mathrm{mg} / \mathrm{kg} \mathrm{ka}\end{array}$ & $\begin{array}{l}\text { alku } \\
\mathrm{mg} / \mathrm{kg} \mathrm{ka}\end{array}$ & $\begin{array}{l}\mathrm{kg} / \mathrm{ha} \\
\text { lisätty }\end{array}$ & $\begin{array}{l}\text { loppu } \\
\mathrm{mg} / \mathrm{kg} \mathrm{ka}\end{array}$ \\
\hline 0-kontrolli & 21,9 & 0 & 21,3 & 8,7 & 0 & 7,3 & 71 & 0 & 66 & 15,0 & 0 & 12,6 \\
\hline Lanta $_{\text {pieni }}$ & 21,8 & 511 & 28,3 & 8,3 & 188 & 7,1 & 74 & 2,6 & 67 & 15,3 & 1,6 & 12,6 \\
\hline Biojäte $_{\text {pieni }}$ & 23,1 & 1570 & 21,5 & 8,7 & 633 & 7,2 & 74 & 4,2 & 66 & 14,5 & 2,9 & 12,8 \\
\hline BioLiete $_{\text {pieni }}$ & 21,7 & 2109 & 20,8 & 8,4 & 764 & 7,2 & 80 & 5,1 & 73 & 20,0 & 3,1 & 15,9 \\
\hline Lanta $_{\text {suuri }}$ & 21,6 & 1003 & 20,5 & 8,5 & 371 & 7,1 & 93 & 5,1 & 86 & 28,5 & 3,1 & 24,8 \\
\hline Biojäte $_{\text {suuri }}$ & 21,3 & 3109 & 20,6 & 8,0 & 1257 & 7,1 & 93 & 8,3 & 81 & 25,6 & 5,8 & 22,4 \\
\hline BioLiete $_{\text {suuri }}$ & 21,8 & 4218 & 21,3 & 8,2 & 1527 & 7,3 & 86 & 10,2 & 78 & 20,9 & 6,2 & 18,0 \\
\hline
\end{tabular}


Tässä tutkimuksessa maan kadmiumin, lyijyn ja kuparin pitoisuudet lopputilanteessa olivat keskiarvoina hieman Mäntylahti \& Laakson (2002) keskiarvoja suuremmat, mutta kuitenkin selvästi vaihteluvälin maksimiarvoja pienemmät. Hatakka et al. (2007) löysivät hienoa hietaa olevilla pohjanmaalaisilla peltolohkoilla hyvin samantasoisia pintamaan raskasmetallipitoisuuksia kuin Mäntylahti \& Laakso (2002), mutta savimaalla Lounais-Suomessa maan keskimääräinen raskasmetallipitoisuus oli korkeampi. Maan raskasmetallipitoisuus vaihteleekin selkeästi maalajin, maakerroksen ja maantieteellisen alueen mukaan (Hatakka et al. 2007).

Jäteperäisissä komposteissa oli enemmän fekaalisia koliformeja kuin lantakompostissa molempina vuosina (Kuva 1). Niitä esiintyi kompostinäytteissä varsin runsaasti keväällä 2004, mikä indikoi kompostien puutteellista hygienisoitumista. Fekaalisia koliformeja oli eniten biojäte-lietekompostissa kumpanakin vuonna, mutta vuonna 2005 määrä oli kaikissa komposteissa hyvin vähäinen edellisvuoteen verrattuna. Tämä kertoo kompostien paremmasta hygienisoitumisesta. Kesällä 2005 fekaalisten koliformien pitoisuudet kompostilannoitetussa maassa nousivat edellisvuodesta poiketen hieman syksyä kohden. Tutkimuksessa käytettyjen kompostien kompostointi oli tehty huolella ja käsittelylämpötilat olivat korkeita, mutta siitä huolimatta osasta komposteja löytyi merkittäviä määriä suolistobakteereita. Kompostinäytteistä löydetyistä fekaalisista koliformeista (Kuva 1) osa oli Escherichia colia ja osa käytetyistä komposteista olisi ylittänyt nykyisin lannoitevalmisteasetuksessa (MMMa 12/2007) määritetyn E. colin raja-arvon (1000 pmy/g). Selityksenä tähän voi olla kompostimassan riittämätön hygienisoituminen kompostointiprosessin aikana tai kompostimassan saastuminen uudelleen esim. lintujen ulosteella hygienisointivaiheen jo päätyttyä.

Maan mikrobiologisten ominaisuuksien perusteella maan laadun heikentymistä ei havaittu; joiltain osin maan toiminta jopa hieman tehostui. Vuonna 2005 typen nettomineralisaatio oli kasvanut Lanta- ja BioLiete-kompostilla lannoitetussa maassa, kun taas Biojäte-kompostilla ei ollut samanlaista vaikutusta (Kuva 2). Näiden tulosten perusteella kompostilisäyksillä ei ole voimakkaita vaikutuksia maaperän mikrobiologisiin ominaisuuksiin, myöskään maamikrobiston kannalta haitallisia vaikutuksia ei havaittu millään kompostilaadulla. Toisaalta matalatkin toistuvat kompostilisäykset kerryttävät maahan potentiaalisesti mikrobiston vapautettavissa olevaa typpivarastoa. Samansuuntaisia tuloksia ovat saaneet tanskalaiset tutkijat yhdyskuntajäte- ja lantakomposteilla (Debosz ym. 2002, Petersen ym. 2003).

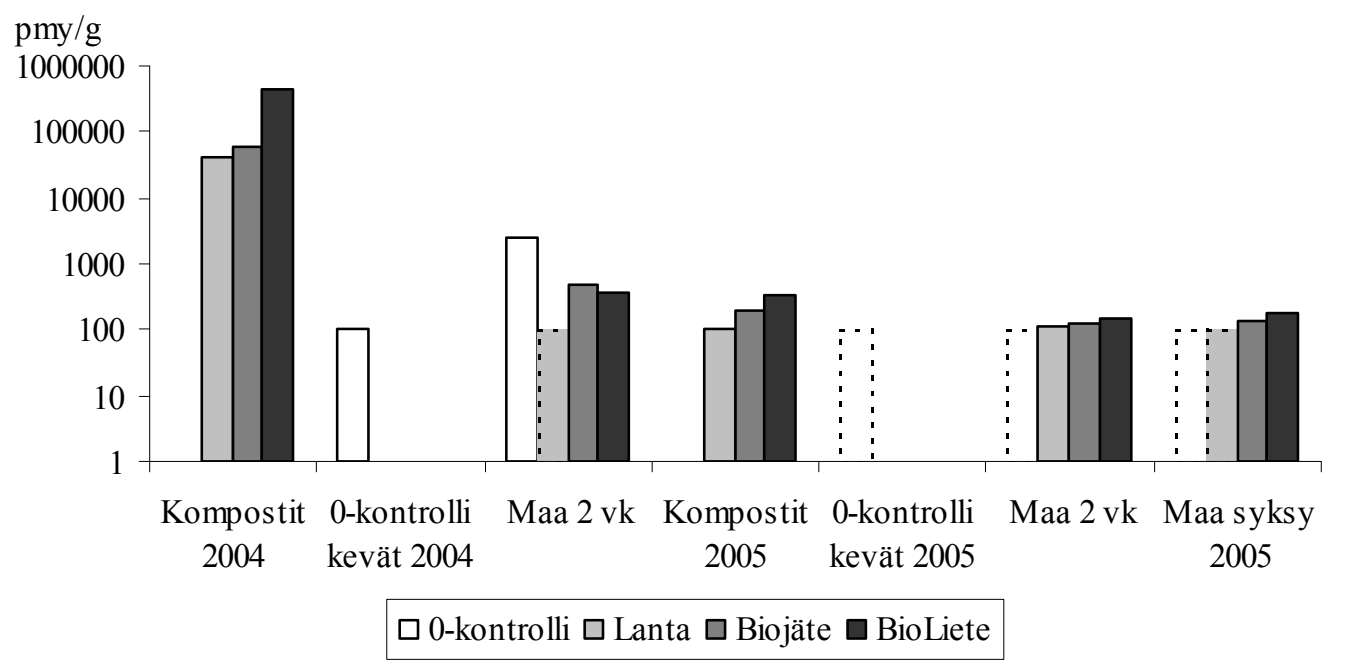

Kuva 1. Fekaalisten koliformien määrä komposteissa ja peltomaassa keväällä kasvukauden alussa, 2 viikon kuluttua kompostilevityksestä (Maa 2 vk) sekä syksyllä 2005 (Maa syksy). Peltomaanäytteet analysoitiin vain kompostien suuremmalla levitystasolla. Mikäli tulos oli alle määritysrajan ( $<100 \mathrm{pmy} / \mathrm{g}$ ), se on merkitty kaavioon katkoviivalla (pmy = pesäkkeen muodostava yksikkö). 


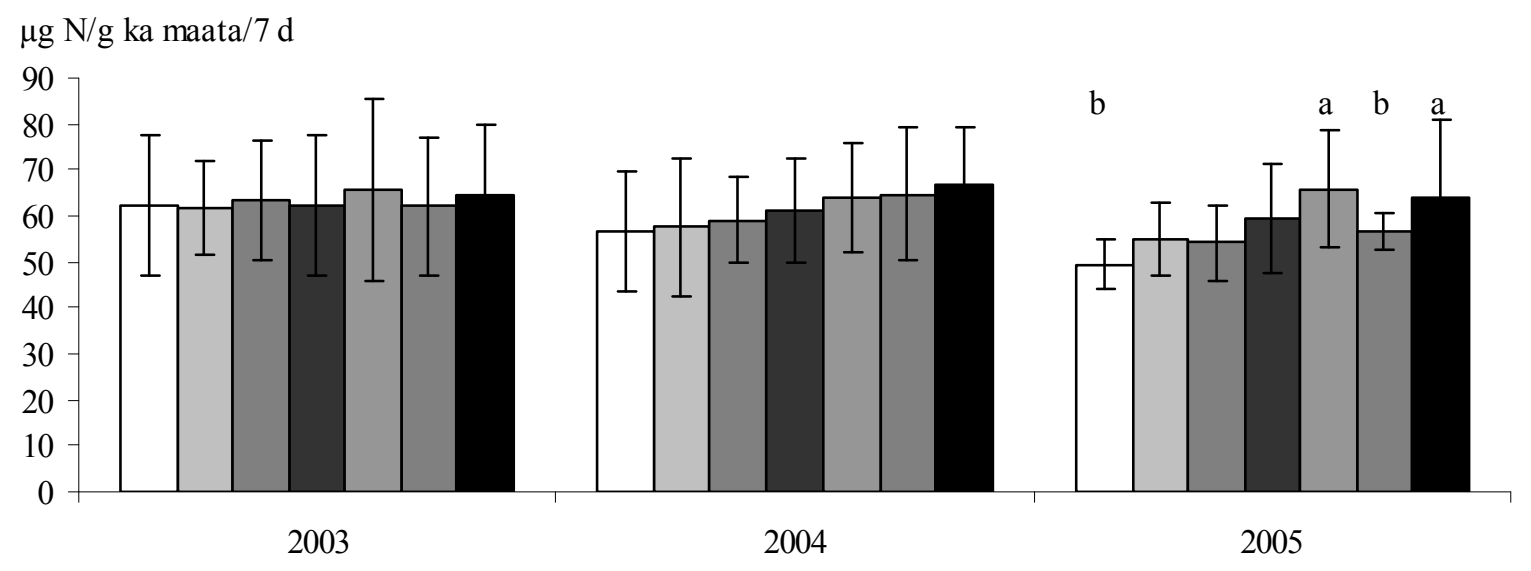

$\square$ 0-kontrolli $\square$ Lanta P $\square$ Biojäte P $\square$ BioLiete P $\square$ Lanta S $\square$ Biojäte S $\square$ BioLiete S

Kuva 2. Typen nettomineralisaatio syksyn maanäytteissä ennen kompostilannoituksia syksyllä 2003 ja kompostilannoitusten jälkeisinä syksyinä vuosina 2004 ja 2005. Keskiarvopylväässä on esitetty keskihajonta, vuoden 2005 eri kirjaimilla merkityt pylväät eroavat toisistaan merkitsevästi $(\mathrm{P}=$ pieni ja $\mathrm{S}=$ suuri levitystaso).

Jätekompostien käytöllä ei havaittu olevan perinteisiä maanparannusvaikutuksia, osittain alhaisten kompostimäärien ja osittain maan hyvän luontaisen viljavuuden vuoksi. Lähes kaikki kompostikäsittelyt lisäsivät levitysvuosien kasvisatoa lannoittamattomaan kontrolliin verrattuna (Kuva 3.). Ensimmäisen vuoden kasvisadon typpisisältö vuonna 2000 vastasi alle $12 \%$ käytetystä kompostitypestä ja vuonna 2005 kasvisadon mukana kokeella korjattiin alle $30 \%$ samana vuonna käytetyn kompostitypen määrästä. Ensimmäisen vuoden jälkeen Biojäte-kompostilla oli kasvisatoa heikentävää vaikutusta, kun taas BioLiete-kompostin vaikutus vastasi melko hyvin Lanta-kompostin vaikutuksia. Kasvisadossa korjatun typen määrä noudatteli kuiva-ainesadon muutoksia.

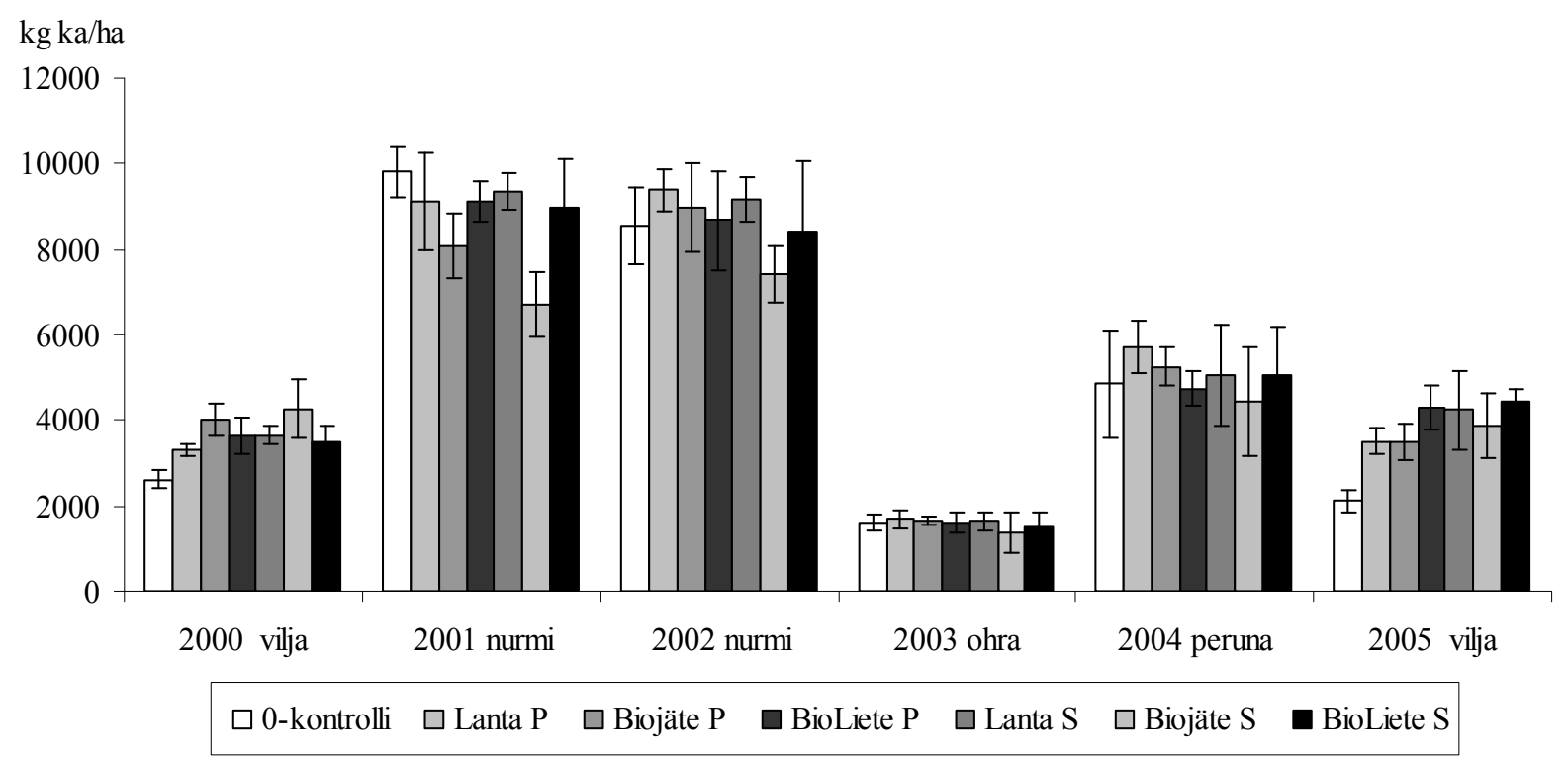

Kuva 3. Kompostilannoituskokeen vuosittainen kasvisato lannoituskäsittelyjen keskiarvoina ( \pm keskihajonta). 


\section{Johtopäätökset}

Tutkimuksessa käytetyillä komposteilla ei havaittu suurinakaan määrinä olevan haitallisia vaikutuksia maaperän biologiseen toimintaan tai maaperän ja sadon hygieeniseen laatuun. Myös komposteista aiheutunut raskasmetallikuormitus oli vähäistä, eikä kompostien vaikutus maaperän ravinnetilaan ollut kovin merkittävä. Lannoittamattomaan maahan verrattuna kompostilla lannoitettu maa tuotti hieman korkeampia satoja kompostien levitysvuosina. Viljelykierrossa oleva apilanurmi toi osaltaan ravinnelisäystä kokeeseen ja kompostien typen vaikutus ilmeisesti haittasi apilanurmen sadontuottoa. Myös välivuonna 2003 ilman kompostilannoitusta kasvatetun ohran sadontuotto oli alhainen, kun taas kompostilannoitetun perunan sadontuotto oli luonnonmukaisen tuotannon satotasoihin verrattuna suhteellisen hyvä. Tulosten perusteella ainakin valikoituja yhdyskuntajäteperäisiä komposteja voitaisiin hyödyntää lannoitteina ja maanparannusaineina ilman merkittäviä haittavaikutuksia. Toisaalta lyhyellä aikavälillä lannoitus- ja maanparannushyödyt eivät ole kovin selkeitä. Jätekomposteilla voitaisiin kuitenkin osittain korvata mineraalilannoitteiden käyttöä ja palauttaa samalla viljelymaahan sadon mukana poistunutta orgaanista ainesta.

\section{Kirjallisuus}

Agricultural Research Centre 1986. Soil and Plant Analysis. Agricultural Research Centre. Department of Soil Science. Jokioinen, Finland: MTT. 45 s.

Bowman, R.A. 1988. A rapid method to determine total phosphorus in soils. Soil Sci. Soc. Am. J. 52: 13011304.

Canali, S. \& Benedetti, A. 2006. Soil nitrogen mineralization. Teoksessa: Bloem, J., Hopkins, D.W. \& Benedetti, A. (toim.) Microbiological methods for assessing soil quality. CAB International, UK. s. 127-135.

Debosz, K., Petersen, S.O., Kure, L.K. \& Ambus, P. 2002. Evaluating effects of sewage sludge and household compost on soil physical, chemical and microbiological properties. App. Soil Ecol. 19: 237-248.

Evira 2007. Luonnonmukainen tuotanto. Lainsäädäntökooste Euroopan yhteisöjen neuvoston asetuksesta 2092/91. Kesäkuu 2007. $28 \quad$ s, 8 liitettä. -Saatavana internetistä: http://www.evira.fi/attachments/kasvintuotanto ja rehut/luomu/luomu_laki/2092-07_heina.pdf. Viitattu: 30.11.2007.

Halinen, A., Palojärvi, A., Karinen, P., Heinonen-Tanski, H. \& Tontti, T. 2007. Jätekompostit lannoitteena peltoviljelyssä - biologiset ja kemialliset vaikutukset. 2. korjattu painos. Maa- ja elintarviketalous 81: $105 \mathrm{~s}$. http://www.mtt.fi/met/pdf/met81a.pdf Verkkojulkaisu (2. korjattu painos) päivitetty 4.10.2007.

Hatakka, T., Mäkelä-Kurtto, R., Tarvainen, T., Laakso, P., Laitonen, A. \& Eurola, M. 2007. Trace elements in top- and subsoil on selected crop and dairy farms in Finland in 2004. Agrifood Research Reports 108. $80 \mathrm{~s}$.

Hänninen, K. \& Mäkelä-Kurtto, R. 1995. Erilliskerätyn biojätteen aumakompostointi ja kompostin käyttökelpoisuus. Pääkaupunkiseudun julkaisusarja C 1995:17. $57 \mathrm{~s}$.

ISO 11466. Soil quality - Extraction of trace elements soluble in aqua regia. -Helsinki: Suomen Standardisoimisliitto. 1. painos 1995-03-01. $5 \mathrm{~s}$.

Lakanen, E. \& Erviö, R. 1971. A comparison of eight extractants for the determination of plant available micronutrients in soils. Suomen Maataloustieteellisen seuran julkaisuja 123: 223-232.

Lehtonen, K., Tontti, T. \& Kuisma, M. 2003. Biojäte-ja lietekompostien käyttömahdollisuudet kasvintuotannossa. Maa- ja elintarviketalous 28: 120 s. +5 liitettä. http://www.mtt.fi/met/pdf/met28.pdf Verkkojulkaisu päivitetty 4.7.2003.

MMMa 12/2007. Maa- ja metsätalousministeriön asetus lannoitevalmisteista. Annettu Helsingissä 13.2.2007. Saatavana internetistä: http://www.finlex.fi/data/normit/28518-07012fi.pdf (Viitattu 30.11.2007).

Mäntylahti, V. \& Laakso, P. 2002. Arsenic and heavy metal concentrations in agricultural soils in South Savo province. Agric. Food Sci. Finland 11: 285-300.

Petersen, S.O., Henriksen, K., Mortensen, G.K., Krogh, P.H., Brandt, K.K., Sørensen, J., Madsen, T., Petersen, J. \& Grøn, C. 2003. Recycling of sewage sludge and household compost to arable land: fate and effects of organic contaminants, and impact on soil fertility. Soil Till. Res. 72: 139-152.

Rajala, J. 2004. Luonnonmukainen maatalous. 2. painos. Mikkeli: Helsingin yliopiston Maaseudun tutkimus- ja koulutuskeskus. Julkaisuja $80.490 \mathrm{~s}$.

SFS-EN-ISO 9308-1 2001. Veden laatu. Escherichia colin ja koliformisten bakteerien toteaminen ja laskeminen. Osa 1. Kalvosuodatusmenetelmä.

SFS 4088. 1988. Lämpökestoisten koliformisten bakteerien lukumäärän määritys kalvosuodatusmenetelmällä.

Vnp 282/1994. Valtioneuvoston päätös puhdistamolietteen käytöstä maanviljelyksessä. Annettu Helsingissä 14.4.1994. Saatavana internetistä: http://www.finlex.fi/fi/laki/alkup/1994/19940282 (Viitattu: 30.11.2007). 